\title{
Properties of $\mathrm{Mn}_{0.4} \mathrm{Zn}_{0.6} \mathrm{Fe}_{2} \mathrm{O}_{4}$ and $\mathrm{Mn}_{0.6} \mathrm{Zn}_{0.4} \mathrm{Fe}_{2} \mathrm{O}_{4}$ as Nanocatalyst for Ammonia Production
}

\author{
Poppy Puspitasari ${ }^{1,3,}{ }^{,}$, Andoko Andoko ${ }^{1}$, Heru Suryanto $^{1}$, Puput Risdanareni ${ }^{2,3}$, Januarti \\ Jaya Ekaputri ${ }^{3,4}$ \\ ${ }^{1}$ Mechanical Engineering Department, Engineering Faculty, Universitas Negeri Malang, Indonesia \\ ${ }^{2}$ Civil Engineering Department, Engineering Faculty, Universitas Negeri Malang, Indonesia \\ ${ }^{3}$ Konsorsium Riset Geopolimer Indonesia (KORIGI), Lab Beton dan Bahan Bangunan ITS, Surabaya, \\ Indonesia \\ ${ }^{4}$ Civil Engineering Department, Faculty of Civil Engineering and Planning, Institut Teknologi Sepuluh \\ Nopember (ITS), Surabaya, Indonesia
}

\begin{abstract}
Ammonia synthesis requires high pressure and high temperature process. Unfortunately, the capital intensive cost resulting low yield of ammonia by using recent catalyst which is iron oxide. Therefore, manganese zinc ferrite as a soft ferrite material will be introduced as a new nanocatalyst to enhance the ammonia yield. As a new nanocatalyst for ammonia production, study of comparasion two different concentration of MnZn Ferrite is very important. This paper will compare the yield of ammonia by using two different nanocatalyst which are $\mathrm{Mn}_{0.4} \mathrm{Zn}_{0.6} \mathrm{Fe}_{2} \mathrm{O}_{4}$ and $\mathrm{Mn}_{0.6} \mathrm{Zn}_{0.4} \mathrm{Fe}_{2} \mathrm{O}_{4}$. Both were synthesized by sol-gel method and has been characterize by using FESEM (morphology), XRD (phase identification), EDX (elemental analysis) and TPR (oxide reduction). The ammonia was produce with and without magnetic field applied. The result shows that the ammonia yield is higher for $\mathrm{Mn}_{0.4} \mathrm{Zn}_{0.6} \mathrm{Fe}_{2} \mathrm{O}_{4}$ nanocatalyst than $\mathrm{Mn}_{0.6} \mathrm{Zn}_{0.4} \mathrm{Fe}_{2} \mathrm{O}_{4}$ by using magnetic field applied. $67.2 \%$ of yield has been achieved by using new nanocatalyst $\mathrm{Mn}_{0.6} \mathrm{Zn}_{0.4} \mathrm{Fe}_{2} \mathrm{O}_{4}$ and magnetic field applied at ambient environment.
\end{abstract}

\section{Introduction}

Ammonia is a chemical substance which has been used as an additive in various applications such as explosives, detergent and about $76 \%$ from the total production of ammonia has been applied in fertilizer industry. Unfortunately, the current production is only capable to generate $10-20 \%$ of ammonia yields with capital and energy intensive. In order to overcome these drawbacks, nanotechnology is seen as an excellent solution. By introducing nanocatalyst which is manganese zinc ferrite $\left(\mathrm{Mn}_{0.4} \mathrm{Zn}_{0} .6 \mathrm{Fe}_{2} \mathrm{O}_{4}\right.$ and $\left.\mathrm{Mn}_{0.6} \mathrm{Zn}_{0.4} \mathrm{Fe}_{2} \mathrm{O}_{4}\right)$ with the new concept of applied magnetic field, the catalytic activity can be induced and the yield can be enhanced.

\footnotetext{
*Corresponding author: poppy@um.ac.id
} 
$\mathrm{MnZn}$-ferrites are considered as one of the great important soft ferrite ceramic materials. This type of ceramics find extensive applications in electronic and telecommunication industry and catalyst. Spinel ferrites combine interesting soft magnetic properties with rather high electrical resistivities [1]. Because of the chemical composition and crystal structure of Mn$\mathrm{Zn}$ ferrite, this material has a high initial permeability, saturation magnetization, and a relatively low eddy current losses compared with alloy cores.

Various processing techniques including conventional and nonconventional have been developed for the synthesis of ferrites. However, each one of these techniques has its specific limitations. Non-conventional techniques such as co-precipitation, thermal decomposition, sol-gel, and hydrothermal, self-propagating high temperature synthesis (SHS) and other wet chemical techniques were widely used [2-5]. The main disadvantage concerns economic and environmental. Therefore, the manufacturing of near fully dense manganese zinc ferrites through minimum number of steps with high magnetic properties will be the focus of this research.

The properties of manganese zinc ferrites depend on their microstructure. The grain size and porosity of the sample will affect the strength performance of the material. One of the main problems during conventional sintering of manganese zinc ferrites is the elimination of porosity. It is well known that the domains structure of magnetic materials is affected by crystal structure, saturation magnetization, magnetocrystalline anisotropy and magnetostriction as well as the size and shape of grains, porosity and crystal defects, which are determined by the processing route [6]. This works deals with the synthesis of manganese zinc ferrite $\left(\mathrm{Mn}_{0.4} \mathrm{Zn}_{0.6} \mathrm{Fe}_{2} \mathrm{O}_{4}\right.$ and $\left.\mathrm{Mn}_{0.6} \mathrm{Zn}_{0.4} \mathrm{Fe}_{2} \mathrm{O}_{4}\right)$ and the ammonia synthesis by using magnetic induction (1Tesla). Both nanocatalyst will compare which one is the best nanocatalyst for ammonia synthesis due to their mole fraction difference.

\section{Methodology}

\subsection{Nanocatalyst Preparation}

The precursor for $\mathrm{Mn}_{0.4} \mathrm{Zn}_{0.6} \mathrm{Fe}_{2} \mathrm{O}_{4}$ and $\mathrm{Mn}_{0.6} \mathrm{Zn}_{0.4} \mathrm{Fe}_{2} \mathrm{O}_{4}$ were prepared by mixing $\mathrm{Mn}\left(\mathrm{NO}_{3}\right)_{2} \cdot 4 \mathrm{H}_{2} \mathrm{O}, \mathrm{Zn}\left(\mathrm{NO}_{3}\right)_{2} \cdot 6 \mathrm{H}_{2} \mathrm{O}$, and $\mathrm{Fe}\left(\mathrm{NO}_{3}\right)_{3} \cdot 9 \mathrm{H}_{2} \mathrm{O}$ with of $65 \% \mathrm{HNO}_{3}$. As-prepared samples were stirred for 1 week and gradually heating until the gel formed at $70^{\circ} \mathrm{C}$. The sample was then dried in an oven at $110^{\circ} \mathrm{C}$ for 24 hours and annealed at $700^{\circ} \mathrm{C}, 800^{\circ} \mathrm{C}, 900^{\circ} \mathrm{C}$, $1000^{\circ} \mathrm{C}$, and $1100^{\circ} \mathrm{C}$ in inert environment for 4 hours.

\subsection{Nanocatalyst Characterization}

The as-synthesized nanocatalysts were characterized by using X-Ray Diffraction (XRD) with $\mathrm{CuK} \alpha$ and $\lambda=1.5418 \AA$, Field Emission Scanning Electron Microscopy (FESEM) SUPRA 35VP, Energy Dispersive X-ray Spectroscopy (EDX), and Temperature Program Reduction (TPR). XRD was used for the identification of phases, crystalline and crystallite size determination. The FESEM gives the microstructure evaluation on the sintered powder. While TPR gives the information about reduction temperature and hydrogen consumption of the samples. The samples of $\mathrm{Mn}_{0.4} \mathrm{Zn}_{0.6} \mathrm{Fe}_{2} \mathrm{O}_{4}$ labeled as sample 1 and the samples of $\mathrm{Mn}_{0.6} \mathrm{Zn}_{0.4} \mathrm{Fe}_{2} \mathrm{O}_{4}$ labeled as sample 2 . 


\section{Result and Discussion}

\subsection{Phase Identification}

Phase identification and lattice parameter were observed using XRD result. The single phase $\mathrm{Mn}_{0.4} \mathrm{Zn}_{0.6} \mathrm{Fe}_{2} \mathrm{O}_{4}$ and $\mathrm{Mn}_{0.6} \mathrm{Zn}_{0.4} \mathrm{Fe}_{2} \mathrm{O}_{4}$ obtained at $1100^{\circ} \mathrm{C}$ sintering temperature (Fig 1 and Fig 2). Intensity of major peak revealed the FWHM, d-spacing and 2 theta degree which also explained the crystallite structure in term of lattice parameter as shown at Table 1 and Table 2. The same value of $a, b$, c were described that lattice parameter of $\mathrm{Mn}_{0.4} \mathrm{Zn}_{0.6} \mathrm{Fe}_{2} \mathrm{O}_{4}$ and $\mathrm{Mn}_{0.6} \mathrm{Zn}_{0.4} \mathrm{Fe}_{2} \mathrm{O}_{4}$ are cubic.

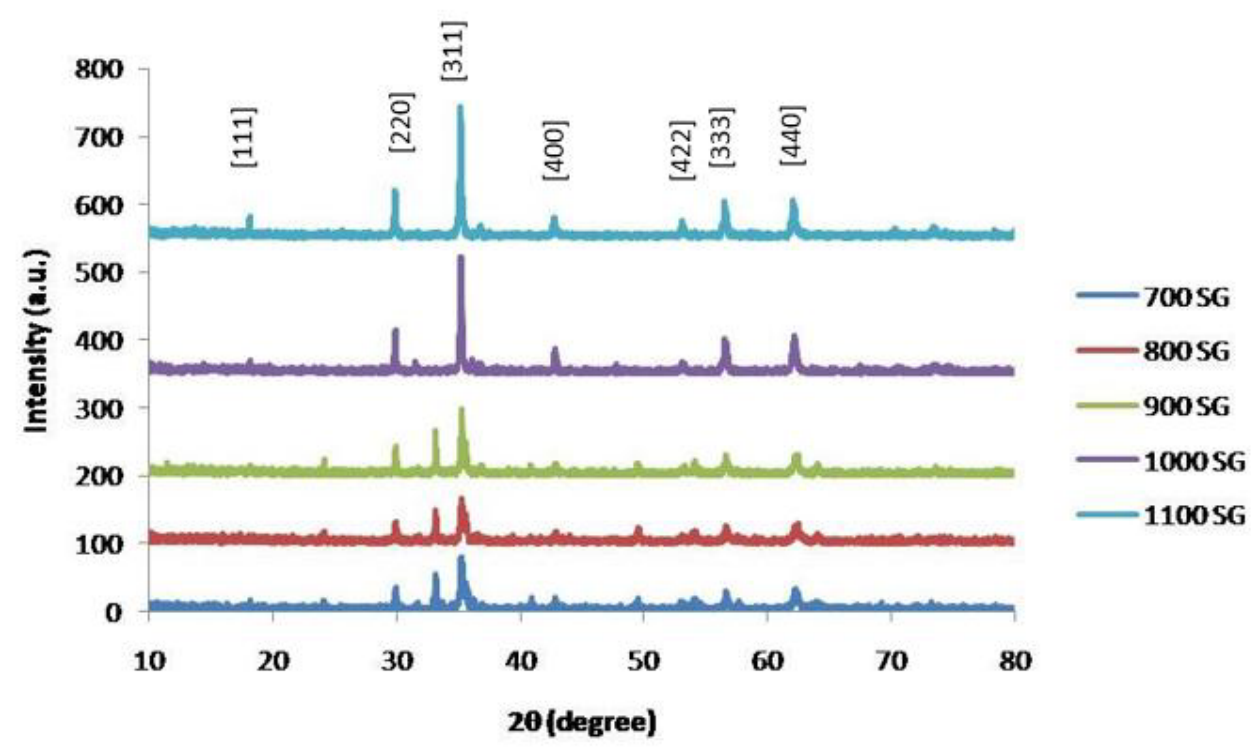

Fig. 1. Phase identification for $\mathrm{Mn}_{0.4} \mathrm{Zn}_{0.6} \mathrm{Fe}_{2} \mathrm{O}_{4}$ synthesized by sol gel method annealed at $700^{\circ} \mathrm{C}$, $800^{\circ} \mathrm{C}, 900^{\circ} \mathrm{C}, 1000^{\circ} \mathrm{C}$, and $1100^{\circ} \mathrm{C}$. 


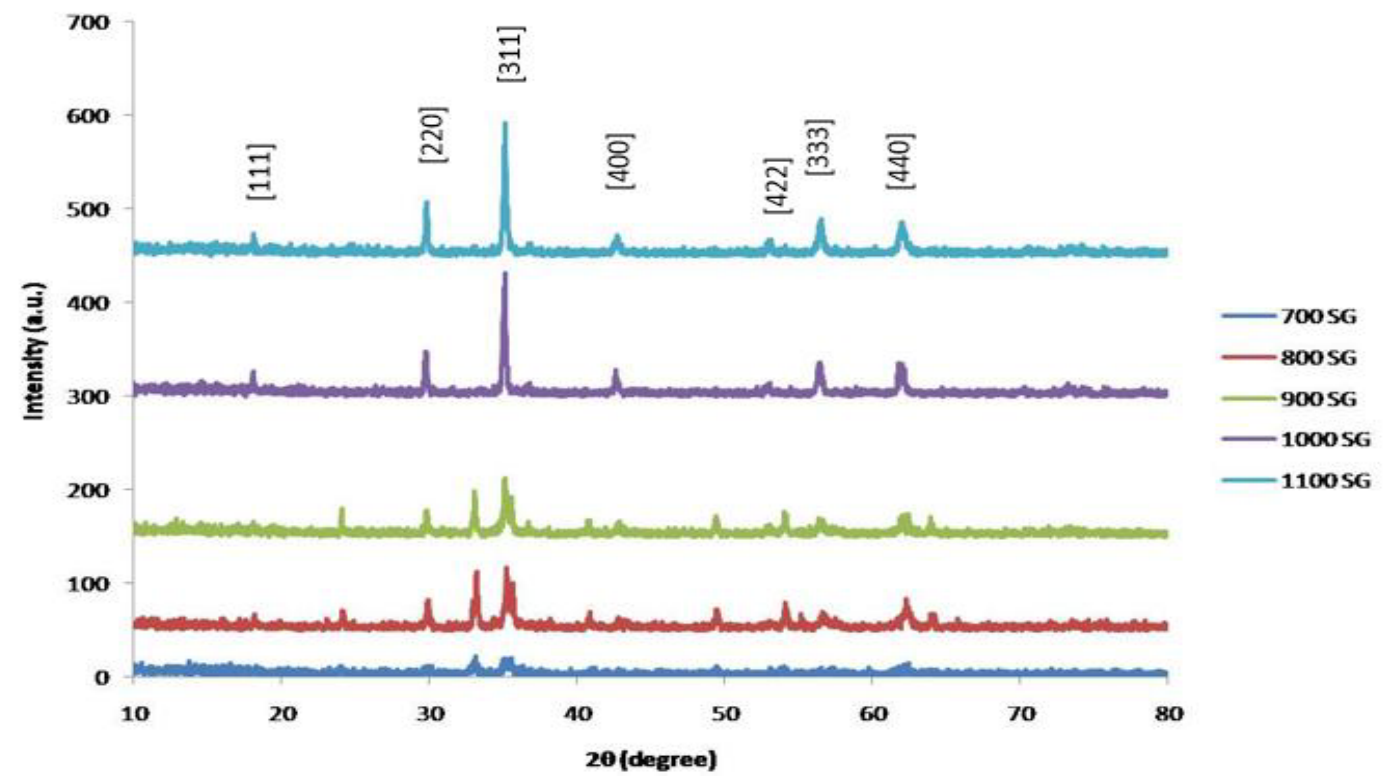

Fig. 2. Phase identification for $\mathrm{Mn}_{0.6} \mathrm{Zn}_{0.4} \mathrm{Fe}_{2} \mathrm{O}_{4}$ synthesized by sol gel method annealed at $700^{\circ} \mathrm{C}$, $800^{\circ} \mathrm{C}, 900^{\circ} \mathrm{C}, 1000^{\circ} \mathrm{C}$, and $1100^{\circ} \mathrm{C}$.

Figure 1 shows the XRD pattern for $\mathrm{Mn}_{0.4} \mathrm{Zn}_{0.6} \mathrm{Fe}_{2} \mathrm{O}_{4}$ at five different temperatures. The highest crystallinity is $\mathrm{Mn}_{0.4} \mathrm{Zn}_{0.6} \mathrm{Fe}_{2} \mathrm{O}_{4}$ annealed at $1100^{\circ} \mathrm{C}$. It shows the single phase nanoparticles at [311] plane according to the standard card SSNNN 89-6609 (C). The samples of 1-700, 1-800, and 1-900 are not single phase since there are another peak appearing as hematite peak. This is because the annealing temperature is not high enough to arrange the atoms to occupied at their own lattice. Whereas, at $1000^{\circ} \mathrm{C}$ the as-synthesized sample shows as single phase with [311] plane. By using the Scherer equation, the crystallite size can be obtain as mention at table I. The crystallite size is getting bigger since the annealing temperature increased. All sample for $\mathrm{Mn}_{0.4} \mathrm{Zn}_{0.6} \mathrm{Fe}_{2} \mathrm{O}_{4}$ shows the hexagonal structure according to the value of $\mathrm{a}=\mathrm{b}=\mathrm{c}$. The smallest particle size is for sample 1-700 which is $70.8 \mathrm{~nm}$. Figure 2 shows the XRD pattern for $\mathrm{Mn}_{0.6} \mathrm{Zn}_{0.4} \mathrm{Fe}_{2} \mathrm{O}_{4}$ at five different annealing temperature. It shows at $1000^{\circ} \mathrm{C}$ and $1100^{\circ} \mathrm{C}$, the as-synthesized samples have formed a single phase at [311] plane. At $700^{\circ} \mathrm{C}$, the samples has not formed into the single phase nanoparticle. It happens because of impurities of the samples and the annealing temperature is not reach the suitable temperature for the ferrite to formed the single phase nanoparticles. The crystallite size can be obtain by using Scherer equation and the values are as mention at table 1 and table 2 . Higher annealing temperature resulting bigger crystallite size. 
Table 1. Value of Intensity, d-spacing, FWHM, crystallite size and lattice parameter of $\mathrm{Mn}_{0.4} \mathrm{Zn}_{0.6} \mathrm{Fe}_{2} \mathrm{O}_{4}$ synthesized by sol gel method.

\begin{tabular}{|c|c|c|c|c|c|c|c|c|}
\hline Sample & Intensity & d-spacing & FWHM & Crystalite size (nm) & 2theta & a & b & c \\
\hline $1-700$ & 78.9 & 2.54 & 0.233 & 70.8 & 35.33 & 8.46 & 8.46 & 8.46 \\
\hline $1-800$ & 67.5 & 2.54 & 0.184 & 89.9 & 35.34 & 8.46 & 8.46 & 8.46 \\
\hline $1-900$ & 96.9 & 2.54 & 0.163 & 102.7 & 35.29 & 8.46 & 8.46 & 8.46 \\
\hline $1-1000$ & 157.0 & 2.54 & 0.131 & 130.8 & 35.30 & 8.46 & 8.46 & 8.46 \\
\hline $1-1100$ & 189.0 & 2.54 & 0.113 & 145.9 & 35.23 & 8.46 & 8.46 & 8.46 \\
\hline
\end{tabular}

Table 2. Value of Intensity, d-spacing, FWHM, crystallite size and lattice parameter of $\mathrm{Mn}_{0.6} \mathrm{Zn}_{0.4} \mathrm{Fe}_{2} \mathrm{O}_{4}$ synthesized by sol gel method.

\begin{tabular}{|c|c|c|c|c|c|c|c|c|}
\hline Sample & Intensity & d-spacing & FWHM & crystallite size $(\mathrm{nm})$ & 2theta & $\mathrm{a}$ & $\mathrm{b}$ & $\mathrm{c}$ \\
\hline $2-700$ & 19.90 & 2.70 & 0.48 & 37.5 & 35.27 & 8.37 & 8.37 & 8.37 \\
\hline $2-800$ & 66.10 & 2.54 & 0.34 & 48.6 & 35.26 & 8.37 & 8.37 & 8.37 \\
\hline $2-900$ & 62.10 & 2.55 & 0.24 & 68.4 & 35.16 & 8.38 & 8.38 & 8.38 \\
\hline $2-1000$ & 122.00 & 2.55 & 0.18 & 89.3 & 35.13 & 8.50 & 8.50 & 8.50 \\
\hline $2-1100$ & 142.00 & 2.55 & 0.16 & 102.7 & 35.10 & 8.50 & 8.50 & 8.50 \\
\hline
\end{tabular}

\subsection{Morphology Analysis}

Figure 3 shows the morphology of samples 1 with different annealing temperatures. At $700^{\circ} \mathrm{C}$, the average particle size is $43 \mathrm{~nm}$ and shows the agglomeration particle. At $800^{\circ} \mathrm{C}$ the average particle is $52 \mathrm{~nm}$. At $900^{\circ} \mathrm{C}$ the average particle size is $63 \mathrm{~nm}$. At $1000^{\circ} \mathrm{C}$ and $1100^{\circ} \mathrm{C}$ the samples were not in the range of nanoparticle size since the particle size is more than $100 \mathrm{~nm}$. Figure 4 shows the morphology of samples 2 at five different annealing temperature. The particle size for $2-700$ is $34 \mathrm{~nm}$ while $2-800$ has average particle size $43 \mathrm{~nm}$. The other sample, 2-900 shows the average particle size 150nm, 2-1000 has bigger crystallite size which is $250 \mathrm{~nm}$ and $2-1100$ has average crystallite size $350 \mathrm{~nm}$. All nanoparticles show the agglomeration and increasing annealing temperature deal with the increasing of the crystallite size. 

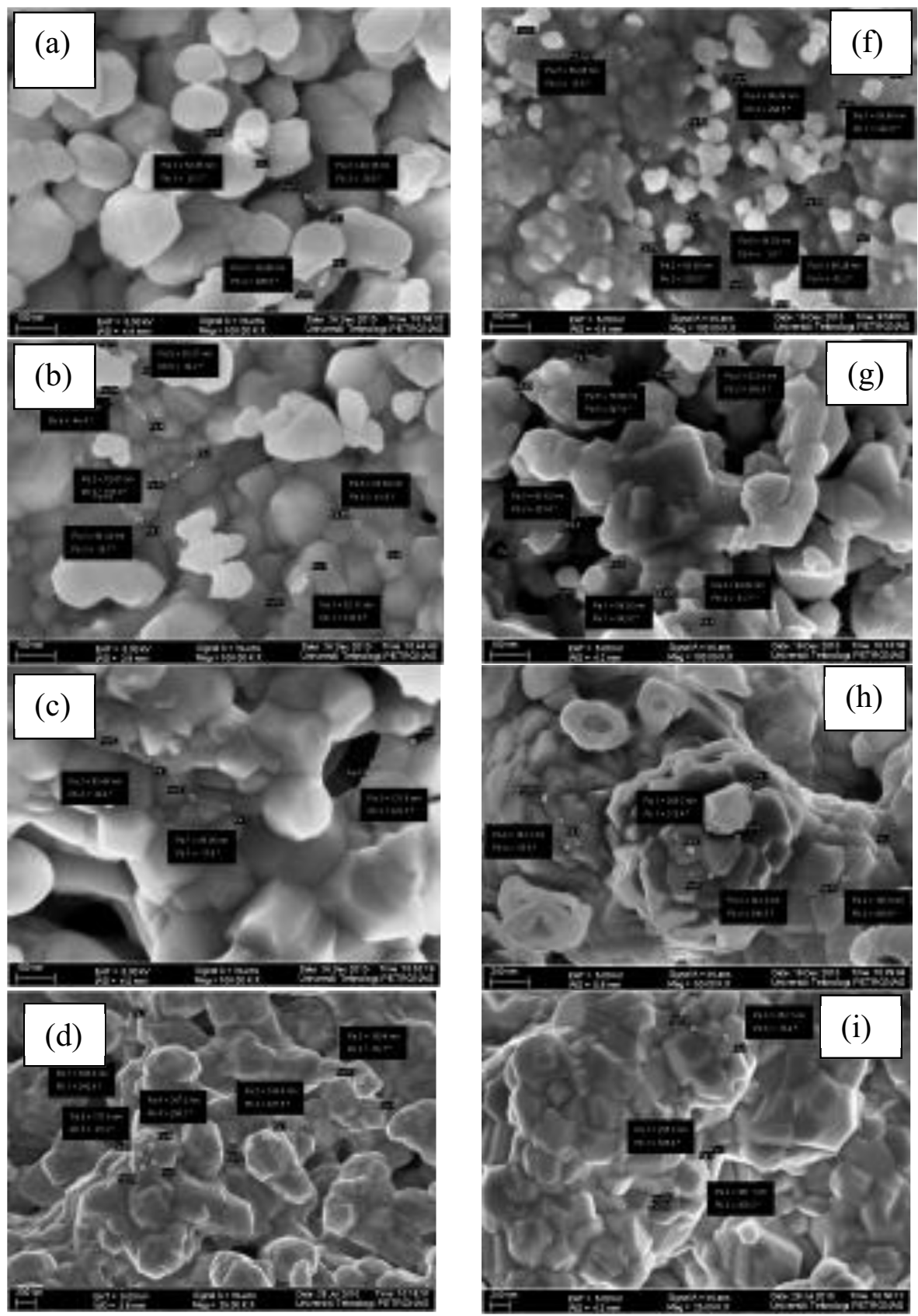


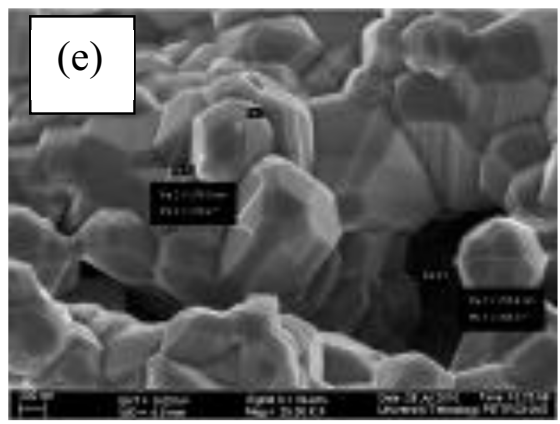

Fig. 3. Morphology of $\mathrm{Mn}_{0.4} \mathrm{Zn}_{0.6} \mathrm{Fe}_{2} \mathrm{O}_{4}$ synthesized by sol gel method and annealed at (a) $700^{\circ} \mathrm{C}$, (b) $800^{\circ} \mathrm{C}$, (c) $900^{\circ} \mathrm{C}$, (d) $1000^{\circ} \mathrm{C}$, and (e) $1100^{\circ} \mathrm{C}$

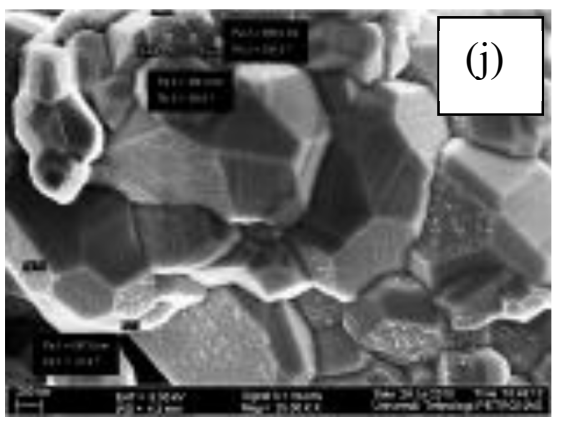

Fig. 4. Morphology of $\mathrm{Mn}_{0.6} \mathrm{Zn}_{0.4} \mathrm{Fe}_{2} \mathrm{O}_{4}$ synthesized by sol gel method and annealed at (f) $700^{\circ} \mathrm{C}$, (g) $800^{\circ} \mathrm{C}$, (h) $900^{\circ} \mathrm{C}$, (i) $1000^{\circ} \mathrm{C}$, and (j) $1100^{\circ} \mathrm{C}$

\subsection{Oxide reduction}

Temperature Programmed Reduction (TPR) was identify reduction of the oxide catalyst to the metallic state. The highest flow rate has been used in this process at $20 \mathrm{ccm} / \mathrm{min}$.

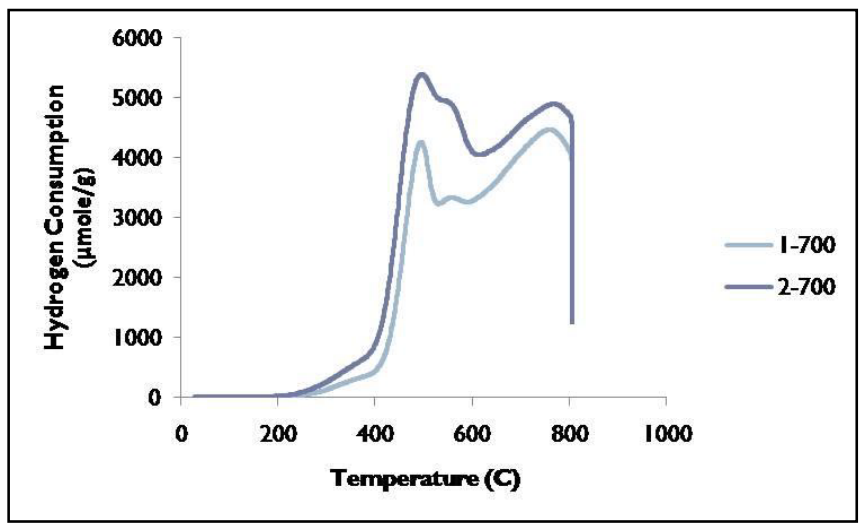

Fig. 5. Reduction profile of samples 1-700 and 2-700

Figure 5 shows the reduction profile for sample 1 and sample 2. It shows that sample 1 needs higher hydrogen consume to reduce the oxide to metallic state. Due to the XRD and FESEM result, sample 2 has smaller particle size $(37.5 \mathrm{~nm})$ compared to sample $1(70.5 \mathrm{~nm})$. Therefore, the percentage hydrogen consumption to reduce is higher for sample 2 . Table 3 provides the information for percentage hydrogen and phase behavior at reduction process for samples 1 and 2. 
Table 3. $\mathrm{H}_{2}$-TPR process for samples 1 and 2 annealed at $700^{\circ} \mathrm{C}$

\begin{tabular}{|c|c|c|c|c|c|c|}
\hline Sample & & 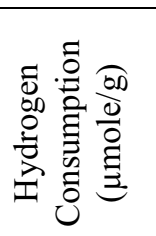 & 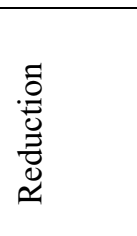 & 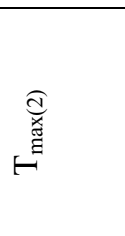 & 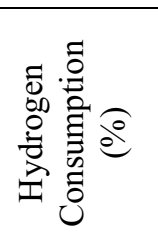 & 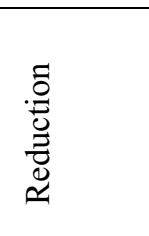 \\
\hline $1-700$ & $478^{\circ} \mathrm{C}$ & 3789.98 & \multirow{2}{*}{$\begin{array}{c}\mathrm{Fe}_{2} \mathrm{O}_{3} \rightarrow \\
\mathrm{Fe}_{3} \mathrm{O}_{4}\end{array}$} & $734^{\circ} \mathrm{C}$ & 4364.93 & \multirow{2}{*}{$\begin{array}{c}\mathrm{Fe}_{3} \mathrm{O}_{4} \rightarrow \\
\mathrm{Fe}\end{array}$} \\
\hline $2-700$ & $476^{\circ} \mathrm{C}$ & 5030.52 & & $767^{\circ} \mathrm{C}$ & 4898.99 & \\
\hline
\end{tabular}

The reduction of $\mathrm{Fe}_{2} \mathrm{O}_{3}$ to $\mathrm{Fe}_{3} \mathrm{O}_{4}$ occurs at $478^{\circ} \mathrm{C}$ for sample 1 and $476^{\circ} \mathrm{C}$ for sample 2 . Other researcher found the reduction of $\mathrm{Fe}_{2} \mathrm{O}_{3}$ occurs at $348^{\circ} \mathrm{C}$ and complete metallic state obtain at $800^{\circ} \mathrm{C}$ [7]. The reduction from $\mathrm{Fe}_{3} \mathrm{O}_{4}$ to $\mathrm{FeO}$ happens at $670^{\circ} \mathrm{C}$ [7]. At this figure, sample 1 shows the middle peak at $559^{\circ} \mathrm{C}$ that can be speculated as the reduction temperature for $\mathrm{Fe}_{3} \mathrm{O}_{4}$ to $\mathrm{FeO}$. Sample 2 shows at temperature $555^{\circ} \mathrm{C}$ the reduction process for $\mathrm{Fe}_{3} \mathrm{O}_{4}$ to $\mathrm{FeO}$ has been occurred. There has been mentioned that amount of zinc will decrease the hydrogen consumption for reduction process [8]. This can be seen from Figure 5 that zinc contain for sample 1 is higher than sample 2 . Thus, the hydrogen consumption for reduction process at sample 1 is lower than sample 2 . At $800^{\circ} \mathrm{C}$ all the oxide has been reduce completely to the metallic state.

\subsection{Ammonia formation}

The formation of ammonia was detected using Kjeldhal Method. The experiment was taken at ambient pressure under five different temperature which were $28^{\circ} \mathrm{C}, 68^{\circ} \mathrm{C}, 108^{\circ} \mathrm{C}, 148^{\circ} \mathrm{C}$ , and $188^{\circ} \mathrm{C}$ to measure the highest yield.

Figure 6 shows the value of ammonia yield using nanocatalyst $\mathrm{Mn}_{0.4} \mathrm{Zn}_{0.6} \mathrm{Fe}_{2} \mathrm{O}_{4}$. The highest yield $67.2 \%$ was obtain at room temperature $\left(28^{\circ} \mathrm{C}\right)$. The yield was decreasing as the temperature increasing. This is due to the effect of currie temperature of nanocatalyst below $100^{\circ} \mathrm{C}[9]$.

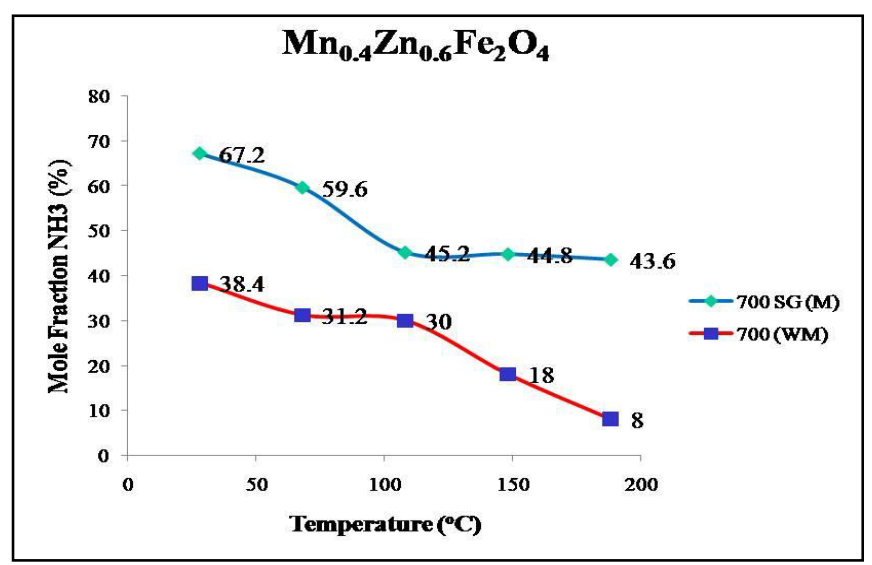

Fig. 6. Ammonia result by using nanocatalyst $\mathrm{Mn}_{0.4} \mathrm{Zn}_{0.6} \mathrm{Fe}_{2} \mathrm{O}_{4}$ 


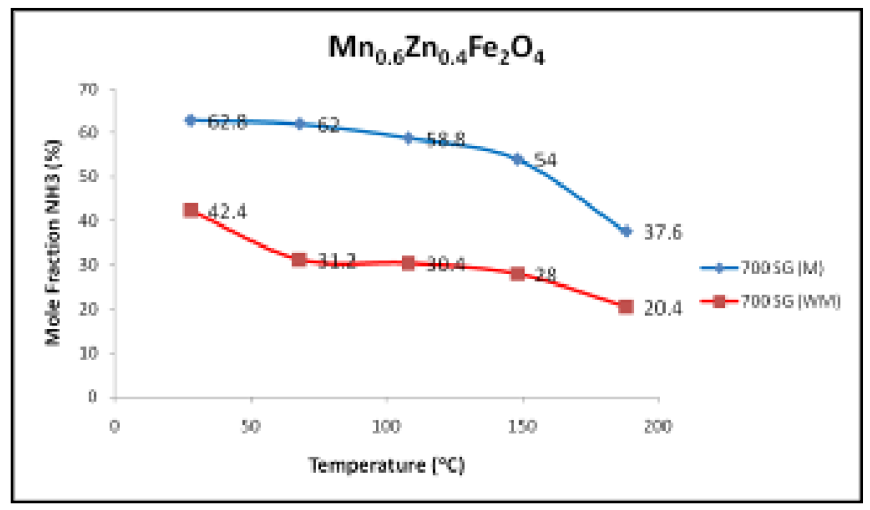

Fig. 7. Ammonia result by using nanocatalyst $\mathrm{Mn}_{0.6} \mathrm{Zn}_{0.4} \mathrm{Fe}_{2} \mathrm{O}_{4}$

Figure 7 shows the value of ammonia yield by using nanocatalyst $\mathrm{Mn}_{0.6} \mathrm{Zn}_{0.4} \mathrm{Fe}_{2} \mathrm{O}_{4}$. The highest yield $62.8 \%$ was obtain at room temperature $\left(28^{\circ} \mathrm{C}\right)$. The yield was decreasing as the temperature increasing.

Both nanocatalyst was obtain the highest yield at room temperature and ambient pressure by applied magnetic field. It has been proven by other researcher that by using applied magnetic field, the yield will increase tremendously compared to the reaction with the absence of magnetic field [10]. This work has a similar condition with other researcher who has been obtain the higher yield of ammonia in the presence of magnetic field by using nanocatalyst $\mathrm{Mn}_{0.8} \mathrm{Zn}_{0.2} \mathrm{Fe}_{2} \mathrm{O}_{4}$ [11]. It was speculated that $\mathrm{Mn}_{0.4} \mathrm{Zn}_{0.6} \mathrm{Fe}_{2} \mathrm{O}_{4}$ posses better spin waves which enhanced the catalytic reaction. The interaction between homogeneous magnetic field in the vicinity of the active centers and magnetic moments of the gaseous particles. In the case $\mathrm{H}_{2}$ and $\mathrm{N}_{2}$, had elevated the production of ammonia in the ambient pressure and room temperature. It is because the electrons in a good alignment which increase the chemical reaction of the process [12]. The best nanocatalyst is $\mathrm{Mn}_{0.4} \mathrm{Zn}_{0.6} \mathrm{Fe}_{2} \mathrm{O}_{4}$ compared to nanocatalyst $\mathrm{Mn}_{0.6} \mathrm{Zn}_{0.4} \mathrm{Fe}_{2} \mathrm{O}_{4}$.

\section{Summary}

The new nanocatalysts from $\mathrm{Mn}_{0.4} \mathrm{Zn}_{0.2} \mathrm{Fe}_{2} \mathrm{O}_{4}$ and $\mathrm{Mn}_{0.6} \mathrm{Zn}_{0.4} \mathrm{Fe}_{2} \mathrm{O}_{4}$ have been used for ammonia synthesis. The $\mathrm{Mn}_{0.4} \mathrm{Zn}_{0.2} \mathrm{Fe}_{2} \mathrm{O}_{4}$ nanocatalyst shows higher ammonia yield $(67.2 \%)$ as compared to the $\mathrm{Mn}_{0.6} \mathrm{Zn}_{0.4} \mathrm{Fe}_{2} \mathrm{O}_{4}$ nanocatalyst (62.6\% ). The excellent ammonia yield has been achieved at ambient pressure and room temperature by applying 1 Tesla applied magnetic field. The TPR result shows that the higher amount of zinc will decrease the temperature reduction of nanocatalyst. Activation energy shows the exothermic reaction for the $\mathrm{Mn}_{0.4} \mathrm{Zn}_{0.2} \mathrm{Fe}_{2} \mathrm{O}_{4}$ nanocatalyst while by using $\mathrm{Mn}_{0.6} \mathrm{Zn}_{0.4} \mathrm{Fe}_{2} \mathrm{O}_{4}$ nanocatalyst the reaction endothermic. From the XRD, FESEM, EDX, and ammonia result, the best nanocatalyst is $\mathrm{Mn}_{0.4} \mathrm{Zn}_{0.6} \mathrm{Fe}_{2} \mathrm{O}_{4}$ compared to $\mathrm{Mn}_{0.6} \mathrm{Zn}_{0.4} \mathrm{Fe}_{2} \mathrm{O}_{4}$. Room temperature and ambient pressure are the most conducive environment to synthesis ammonia because it is easy to control, safe and cost effective.

I would like to express my gratitude to Ministry of Research, Technology and Higher Education (RISTEK DIKTI) for the financial support under Penelitian Unggulan Perguruan Tinggi (PUPT) batch 2016. 


\section{References}

1. Emad M. M. Ewais, Mahmoud M. Hessien, Abdel-Hady A. El-Geassy, J. Aust. Ceram. Soc., 44, 57 (2008)

2. L. Nalbandian, A. Delimitis, V.T. Zaspalis, E.A. Deliyanni, D.N. Bakoyannakis, and E.N. Peleka, Micropor. Mesopor. Mat., 114, 465 (2008)

3. P. Puspitasari, N. Yahya, N.A. Zabidi, N.A. Ahmad, International Journal of Applied Sciences, 11(7), 1199 (2010)

4. M.M Rashad, Mater. Sci. Eng. 127(2), 123 (2006)

5. Lai Zhenyu, Xu Guangliang, Liu Min, A. Ahniyaz, M. Yoshimura, J. Wuhan Univ. Technol. Mater. Sci. Ed., 23(2), 151 (2008)

6. S. Kazemi, G. Fantozzi, Mater. Sci. Eng. A, 442(1), 496 (2006)

7. A. Khan, P.G. Smirniotis, J. Mol. Catal. A: Chem., 280(1), 43 (2008)

8. Meisheng Liang, Wenkai Kang, Kechang Xie, J. Nat. Gas Chem., 18, 110 (2009)

9. S.R. Janasi, D. Rodrigues, F.J.G. Landgraf, Mater. Sci. Forum, 498, 119 (2005)

10. N. Yahya, P. Puspitasari, K. Koziol, P. Guiseppe, Ammonia Synthesis in Carbon and Oxide Nanostructure (Springer, Berlin Heidelberg, 2010)

11. N. Yahya, P. Puspitasari, K. Koziol, N.A.M. Zabidi, M.F. Uthman, International Journal of Basic and Applied Sciences, 10 (1), 95 (2010)

12. R.Y. Hong, Y.J. Wu, B. Feng, Q.D. Di, H.Z. Li, B. Xi, Y.Z. Heng, D.G. Wei, J. Magn. Magn. Mat, 321(8), 1106 (2009)

13. S. Arrhenius. Z., Phys.Chem, 4, 226 (1889)

14. A.F Dethlefsen, E. Mariani, W. Wegscheider, R.J Haug, Physica E., 34, 108 (2008) 